\title{
HOW EXTENSIVE CREATIVITY IS RELATED TO THE ESCALATION OF VIOLENCE IN ART?
}

\author{
Anatoliy Igorevich STOLETOV ${ }^{1}$, Rushana Khusainovna LUKMANOVA², \\ Miliausha Faritovna SIRAZETDINOVA ${ }^{3, *}$, Ksenia Vyacheslavovna KHRAMOVA ${ }^{4}$, \\ Olesya Gennadyevna AFANASYEVA ${ }^{5}$ \\ ${ }^{1}$ Bashkir State Agrarian University, Faculty of Agricultural Technologies and Forestry, Department of \\ Socio-Economic Disciplines and Humanities 50 let Oktyabrya ul. 34, Office 356/1, Ufa 450001 Russia \\ ${ }^{2}$ Institute of History and Public Administration, Department of Foreign History, \\ Tukaev ul. 1 (entrance from Karl Marx ul. 3/4), Building 3, Office 519, Ufa 450015, Russia \\ ${ }^{3}$ Bashkir State University, Scientific and Organizational Department, \\ Tukaev ul. 1 (entrance from Karl Marx ul. 3/4), Building I, Office 501, Ufa 450015, Russia \\ 4, ${ }^{5}$ Bashkir State Medical University, Faculty of Dentistry, Department of Philosophy, \\ 47 Validi ul., 450000 Ufa, Russia
}

Received 11 March 2019; accepted 25 June 2019

\begin{abstract}
Film, dramaturgy and literature exhibit increasingly more episodes of cruelty in the interactions between the characters. With its focus on the core ideas about escalation of violence, this paper examines the fundamental reasons for the upsurge in depictions of violence in art. The article demonstrates social, cultural and anthropological factors contributed to shaping the technosphere which impedes the comprehension of the relationship and the contrast between life and death. Without this comprehension, a cultural dysfunction entails the existential crisis, hinders feeling fully alive, and provokes a "safe" virtual way to generate a limit situation that restores "life's integrity" experience. Art that demonstrates violent scenes is one of these methods. In addition, and this is the first paper to analyze this, the extensive type of creativity dominates the postindustrial society culture. Research demonstrates that extensive creativity does not contain an ethical component and nor foster immunity to violence. On the contrary, by directing an individual towards exploring and transforming the external world, it provokes violence, since the nature of expansion is a priori forced. The authors conclude that escalation of violence in art testifies to the deficit of cultural methods that allow to satisfy a person's existential needs.
\end{abstract}

Keywords: aggression, contemporary art, cruelty, existential needs, extensive creativity, film, technogenic civilization, violence.

\section{Introduction}

Similar to a mirror that reflects the one looking at it, contemporary art (CA), if we agree with the definition given to it by Oscar Wilde (2000), portrays a society where various forms of

*Corresponding author. E-mail: glavredsirazi@gmail.com

This is an Open Access article distributed under the terms of the Creative Commons Attribution License (http://creativecommons. org/licenses/by/4.0/), which permits unrestricted use, distribution, and reproduction in any medium, provided the original author and source are credited. 
cruelty and violence are common occurrences. Psychologists, social scientists, art experts, scholars of ethics, aesthetics, and cultural studies discuss this tendency of the escalating violence and its impact, ways of countering violence and assisting the victims. Notably, the United Nations General Assembly had endorsed The 2030 Agenda for Sustainable Development, conceding to the need to prevent the growing scale of violence and its origins, "insecurity and injustice, such as inequality, corruption, poor governance and illicit financial and arms flows, are addressed in the Agenda” (2015, p. 9).

Pragmatic issues of aggression and violence have been the object of recent Englishlanguage research in medicine, psychiatry and psychology (Tzavaras, Krasanakis, \& Giannoulaki, 2013; McNally, 2002), education (Addison, 2011), gender (Corcoran \& Lane, 2018; Fobear, 2017), and cultural (Anderson Hudson \& Wadkins, 1988) studies.

Few scholars have conceptualized the origins of growing scale of violence. In the fourth article in a series of fifteen papers aimed at eliminating this omission, Bandy X. Lee claims that symbolic human nature stipulates for the ability of art and religion to become a powerful means to express violence which are abundant in symbols that play a determinative role in cognitive and emotional development (2016, p. 153).

The research goal is to elucidate the underlying reasons for the rise in the number and the increasingly naturalistic nature of violent scenes involving both contemporary artwork observers and creators. The object of research is the reason for escalation of violence reflections contemporary in art.

Research hypothesis suggests that the need for the naturalistic and extensive scenes of violence in CA is determined by the need to restore the balance between life and death, disrupted by the indulged living conditions. The latter, in today's society, shield people from the incessant need to struggle for sustenance (liberation) and reduces cultural creativity producing existential values.

Research questions are as follows: What are the causes for "normalization" or attractiveness of violence in art that lead to its escalation, and how are they manifested? May the technization and innovative focus of contemporary creativity theirself raise the violence presence in art and life, and which anthropological factors may be primary or supplementary?

The remainder of this article is organised as follows. From a brief description of the clear tendency towards increasing violence in art in Section 2.1, we proceed to the aspiration to elaborate, detail (naturalism) and refine its forms (aestheticization) in Section 2.2. The following sections attempt to restore the sequence of society's social and cultural parameters and basic human psychological needs (Sections 2.3-2.5) in order to demonstrate how the combination of tendencies in the development of society with the human beings' idiosyncrasies shape the representation of violence in CA (Discussion).

\section{Method}

We proceed from the idea that art does not merely describe pathological thinking and behavior, but fills up with projections and identifications of unconscious feelings (Tzavaras et al., 2013). A tool for the analysis of creative activity is Erich Fromm's theory of the subject's relationship with the surrounding world and people, namely, his concept of existential human needs (1973). 
This study relies on the understanding of art within a social system that reveals general systemic characteristics. Combining historical analysis to juxtapose the past and the present and identification of the specific violence manifestation forms in artworks allowed to reveal the sociocultural origins of the process under consideration. The concept of two creativity types that allowed to characterize the state of contemporary culture (Stoletov, 2016).

\section{Results}

\section{1. Naturalism and extensive scale of violence in contemporary art}

Art, which has supported humankind throughout its history, has always heeded a certain share of attention to violence and cruelty. However, being an aesthetic object in the art of the times past, violence had not extended to naturalism in accordance with the aesthetic distancing nature of artistic reality. For instance, classical aesthetics prohibited making suffering to look naturalistic, as it is linked with aggression in one shape or another, was through the aesthetic substantiation of the ideal of beauty.

In his analysis of the ancient Greek composition Laocoön and His Sons, Gotthold Ephraim Lessing maintains that depiction of utter suffering falls beyond the aesthetic field's scope. The sculptor depicted Laocoön groaning, rather than screaming, while he fights the snake, because screaming "distorts the face repulsively" (Lessing, 1953, p. 359). Classical aesthetics, based on the primacy of the beautiful over the ugly, the majestic over the lowly, perceives violence as the dark side of the Moon. It is a part of this world, but is allowed into artwork only to the extent that it does not interfere with observing the light.

In the 20th century with its non-classical, and, subsequently, post-non-classical paradigm in art, after the social upheavals, anthropological, linguistic, ethical and other "turns" violence changes its status. It increases on an extensive scale, and, what is of even greater interest, a higher degree of naturalism. Once again invoking the classical image of an ancient Greek augur Laocoön, it is apparent that in CA he chokes on his screams increasingly more often than groans. This is particularly consistent with film industry, a younger art that combines the qualities of both spatial and temporal classical types of artistic creativity. Even reasonably high-quality films have not been overlooked either by consumers or film experts in order to see numerous episodes with very realistic scenes of murder, frequently of a mass nature - Kill Bill: Volume 1 (director Quentin Tarantino, 2003) and Kill Bill: Volume 2 (director Tarantino, 2004), Saving Private Ryan (director Steven Spielberg, 1998), Braveheart (director Mel Gibson, 1995), Apocalypse Now director Francis Ford Coppola, 1979).

Information technologies expand this potential even further. However, it is not just about the technology. Gaspar Noés film Irréversible aroused much controversy in 2002 with two exceptionally detailed scenes - a rape of a woman in an underground passage and a cruel murder of a nightclub visitor. The film's impact is not merely due to the use of computer image manipulation, but to the length and naturalistic quality of the scenes filmed with a single shot. With no cuts or edits, it demonstrates their characters on an emotional peak, seemingly without restrictions or conventions, similar to a reality show.

The audience finds comparable situation to exist in literature as well. If one singles out the epic fantasy genre (i.e., J. R. R. Tolkien's series of books about Middle-Earth) as an illustra- 
tion, and add some naturalism to it, he might get one of the cult books of the second half of the 20th century, Song of Ice and Fire (Martin, 1996, 1998, 2000, 2005, 2011, forthcoming a, b) by George R. R. Martin. The novel stunned the readers not only, or even primarily, with the detailed world and characters, typical of Martin's predecessors as well, but also with the abundance of erotic scenes, cruel murders, sudden plot twists linked to characters' deaths, absence of a group of univocally positive characters, customary for fantasy, or a tendency for the victory of good over evil. A series created basing on this storyline, wherein the first parts followed this naturalistic atmosphere in depicting all types and varieties of violence, subsequently tempered in order to expand the audience.

\section{2. Aestheticization and visual appeal of violence}

Scholars diverge in their evaluation of why artistic reality contains increasingly more violence and cruelty. In regard to post-modernist aesthetics, one may encounter both "accusatory" publications and "exculpatory" ones. The first ones charge post-modernist aesthetics since it fails to comply with its essential duties to discover and bring harmony in reality, which is destructive, opposes to cultural icons (Rodionov, 2008, p. 30), and depends on mood, on which the victim's fate is contingent (Tropina, 2009, p. 16).

The second ones, which reveal the simulative nature of human activity and the genesis of violence in the routine practices of everyday life (Nemchenko \& Temlyakova, 2015; Lobastov, 2009). CA "mimetically reproduces all different kinds and options of violence, which origin from historic cataclysms, in particular, military operations and revolutionary struggle" (Nemchenko, 2013, p. 136), and postulates the author's and the perceiver's value judgement. Due to the statistical violent crime rate increase, there is criticism of popular media for predictably violent contents. Violence towards a person in art is horrifying when the spectator is not one of those who assert himself through violence and dismisses the boundaries of decency and the rule of law.

Vsevolod Vladimirovich Ferroni holds reason for a rise in crime to be rooted in an "aesthetic" aspect of human existence, namely, aestheticism and heroism, counteracting the formality of the "external" institutional culture (2015). The post-Soviet "new drama", an example of the "theater of cruelty", thus its slang and obscenities, has become one of the foremost and most ambiguously assessed genres. Here, an individual is not compelled to fight evil, but is forced to dedicate all capabilities to the struggle for sustenance a typical. Taking into account the past and the present of Russia, it is difficult to envision that violence, cruelty, aggression issues as a whole and in art in particular might become irrelevant for Russian art.

In her studies of screen violence and its aestheticization in contemporary culture, Inessa Tropina (2009) attempts to disclose the ethical and aesthetic principles as levels of screen violence "coding". She found that aestheticism as a way of life leading to the switch from non-visually appealing, euphemized forms of violence in film to visually appealing ones. Aestheticism, conceived in line with Søren Kierkegaard's gaze (Maffesoli, 1989), finds expression in the heightened interest in human manifestations of corporality (living body), vitality and spontaneously emotional sides, which take forms of striving for sensual pleasures and low-priority for moral judgement. 
This compensatory type of violence displays itself in the emotionally "exhilarating" artistic form, leading to a steady rise in the proportion of violence and cruelty and the naturalism in their depictions. To realize an individual's existential needs (ENs) in the described "virtual", quasi-compensatory form, a viewer faces an artificial "limit situation", maintaining a sense of the true existence experience, however, without real risking his life.

\subsection{The psychological side of violence in art}

Dramatic arts join the declared by Lev Shestov "apotheosis of groundlessness" (1920) trend, entailing the Nietzschean "death of God", utter loneliness, and absurdity of existence. The axiom of groundlessness advocates Antonin Artaud's (1994) "theater of cruelty", further developed by Peter Brook and Jerzy Grotowski:

'Grotowski's and Brook's experiments with the 'theater of cruelty' follow new cultural compasses. Both director and performers suggest to eliminate rational and ethical limitations during the performance, seeking to shock the viewer by violating cultural norms, and destroying stereotypical understanding of the outside and the inner world" (Chetina, 2012, p. 145).

Aggression demonstrated by living beings in their vital activities stipulates the psychological aspects of violence. Having accumulated in his studies the behaviorist, neurophysiological and ethological research on aggression and cruelty as innate human qualities, along with psychoanalytical findings, Fromm believes that benign aggression is supportive of survival and personal development. He distinguishes it from malignant aggression, growing along with civilizational development and manifested in cruelty:

"The human passions transform man from a mere thing into a hero, into a being that in spite of tremendous handicaps tries to make sense of life. He wants to be his own creator, to transform his state of being unfinished into one with some goal and some purpose" (Fromm, 1973, pp. 8-9).

Passion may satisfy creative desires in different ways: from positive, constructive and exalted to negative, vile and destructive. In the 1980s, studies of manga and other comics that either stress violence, held them to be avenues of escapism in a society where authorities provide a constitutional prohibition on war, tough weapons control and an extremely low crime rate.

Lee demonstrated that a healthy bio-psycho-social state implies feeling vigorous, creative, and alive. The need not fulfilled leads to dissatisfaction contributes to violence manifestations. When a person fails to find out legal and socially acceptable means of self-expression, he or she resorts to violence in attempts to emulate creativity by applying excessive energy instead of lacking true vitality (Lee, 2016, p. 154). Repressions, conformism and the hierarchical structure of the society have increased the need for the demonstration of emotions and fantasies in advertising, comics and films that enjoyed success in Japan (Anderson Hudson \& Wadkins, 1988, pp. 270-271).

Humans and the humankind have been keeping a balance, supporting the delicate equilibrium among the contradictory facets and dimensions of their existence (Fromm, 1973). Fromm considers freedom to be one of the fundamental prerequisites of this equilibrium's 
viability. However, as he demonstrates in another work, while increasing the degrees of freedom in one sense, civilizational progress restricts it in others. Becoming excessive, freedom gives a rise to the occurrence of a totalitarianism as an "escape from freedom" (Fromm, 2013). The stressful social pressure of civilization empowers defence mechanism of displacement and a sublimation. The society grants a person an illusion of stability and equilibrium, relieving an individual of difficult choices and responsibilities exchange for their obedience and belonging to a giant social machine. Stripping a person of freedom and self-realization ruins personal creativity and breeds a compensatory form of violence.

\title{
2.4. Authority and creativity realization in the portrayals of violence
}

In his The Revolt of the Masses (originally published in 1929), José Ortega y Gasset demonstrated that, while increasing the level of comfort and prosperity, scientific and technological progress does not necessarily decrease the pressure on the individual. This gives rise to new, soft varieties of violence and refines restrictive applications of the scope provided by sociopolitical institutions. He concedes that the escalation of Western civilization's technological might leads to the emergence of a state machine, which suppresses the individual's free selfactualization (Ortega y Gasset, 1932, pp. 116-117). Even in the technologically advanced countries, the state machinery's pressure is rather strong and shaped in a variety of aesthetic forms, in the same way it did in the feudal period (Anderson Hudson \& Wadkins, 1988).

Lewis Mumford (2004) refers to the social system developed over the past century as to a megamachine, and Slavoj Žižek - discusses the objective, "systemic" violence, which uses any and all means to attain governmental goals (2008, p. 206) and turns language and art into instruments violence. He describes a discernible difference between the motivations for technical solutions of past and present societies:

\begin{abstract}
"Aesthetic inventions played a no lesser role in man's attempts to create a meaningful world than practical needs; and due to their requirements, they also served as a significant stimulus for technological development [...] essentially, every structure, due to the combination of volume, mass, color, ornamental decorations, texture was a new invention, which expressed and modified the idea of the relationship between a man and the universe. A pyramid, an obelisk, a tower, an ark, a cupola, a spire, an intersecting vault, a scaffold prop, a stained-glass window - these are just a few examples of the unbridled technical audacity, which was carried into effect not in order to satisfy physical needs or a desire for material prosperity, but in the course of a more profound search for meaning" (Mumford, 2004, p. 243).
\end{abstract}

For technology of the past, the search for a deeper meaning was a driving idea behind the acts of invention, and the devices theirself were relevant not only to the level of material prosperity, but to an individual's ENs as well. Contemporary engineering, very close to scientific activities, remains to develop material well-being and comfort, concurrently losing much of its desire to find meaning. John Naisbitt refers to this state as "technology intoxication", with one of its symptoms that those living amidst high technologies accept violence as a norm, drawing parallels between the 1998 film Small Soldiers (director Joe Dante, 1998) and the tragic events in Springfield, United States (2001, pp. 23-24, 94). 
Attaining sustainable development may signify a common simulacrum of comfort, which suppresses ENs, reducing them to aesthetic pleasure, when everything is "made pretty". The mechanized and smoothly functioning society of 20th century's society had already caused the criticism and the protests, conceived in a spectrum of counterculture trends - hippies, rock music, punks who did not want to be the cogs in the social megamachine.

On another front, creativity may go beyond the limits imposed by morality or ethics in order to preserve health and social order. Lynn Corcoran and Annette Lane (2018) partially confirm this fact on the example of gender violence reflected in visual arts at recent public exhibitions. They revealed that emotional engagement and relief, which augments the intellectual interaction with the artwork, helps to deeper percept and understand the essence and consequences of violence. At their best, artworks make it easier to inform, study and learn more about violence.

Katherine Fobear (2017) goes further to describe LGBT-refugees' experience in Canada. Instead of simply sharing their grim experience of violence in the framework of an art project, they counteract discrimination, negative stereotypes and standard discourse that creates an image marginalizing LGBT refugees. Art that centers on the common to the participants theme of violence, helps to restore the joy of communication. They create a safe space for information exchange, humor, education and recovery, otherwise traditionally limited to their roles of victims suffering from isolation, sadness and anger.

Nicholas Addison (2011) concludes that the collective act of accepting the portrayals of violence demonstrates a deep connection between violence, spontaneity and the sexual principle, which is typically associated with creativity. He holds the view that similar, but isolated acts indicate violations or divergences not merely strange or provocative, but often caused by trauma. However, one cannot rule out the possibility that ritual violations of ethical norms may easily transform into a fascist spectacle of increasingly more violent actions where the affective flow unites the people who are following the leader.

Addison used Donald Winnicott's (1971) concept of potential space when describes the imagined, although not simply psychological or internal, space of action, where the students may explore dichotomous situations of tension between external and internal forces, between the enabling and policing roles. With a specific experimental task to create anonymous works not complying with standard rules, the potential space navigated the students through situations of tension (Addison, 2011, pp. 172-173).

This potential space apparently included scenes of violence. Students have depicted landscapes of violent interactions that symbolize and concurrently relieve the perceived relations of power. Genre-wise, the drawings were excessive - violent sexualization and grotesque are used as an antidote that restricts creative freedom with the guidance of a "regular" teacher. Addison concludes that the game and symbolic aggressive relations' forms become a required component of health, unacceptable in the real society with its morals, for instance, in the context of mutual humiliation or crimes justified by the goal of establishing social order.

Hence, depiction of violence endorses the use of aggressive, emotional energy as a sacrifice to liberate transformative, creative actions, rather than to spread violent practices. 


\subsection{Scarceness of existence in a technogenic civilization}

Spiritual sterility contributes to an excessive scale of violence production, which escalates to systemic proportions. Alfonso Cuarón's feature film Children of Men (2006), depicting a world devoid of a future, since people have lost the biological ability to reproduce, stands out in a lineup of numerous films devoted to this issue. However, as Žižek rightfully notes,

"Children of Men is obviously not a film about infertility as a biological problem. The infertility Cuarón's film is about was diagnosed long ago by Friedrich Nietzsche, when he perceived how Western civilisation was moving in the direction of the Last Man, an apathetic creature with no great passion or commitment. Unable to dream, tired of life, he takes no risks, seeking only comfort and security, an expression of tolerance with one another" (2008, p. 28).

However, the director does give hope to humankind. Total violence can only be stopped by a miracle - by the sight of a living baby born right in the middle of hostilities. Everything is upside down in this artwork's world. While previously the fullness of life in a limit situation was linked to the slumber of death, Cuarón depicts an inverted limit situation. The totality of life here is linked not with the observing or experiencing death, but with the miracle of life.

When faced with the feeling of life's incompleteness, some people attempt to overcome it through high technologies. Elena Nekrasova finds a rationale behind spreading homemade humiliating scenes filmed using a smartphone and published online:

"Everything is secondary in this video aside from one thing - the emotional outburst that follows the violence. Emotions the victim experiences in front of the camera are absolutely genuine. One may attempt to copy the circumstances of violence and the behavior of the operator, but the victim's reaction will always be spontaneous and truly genuine. The victim will experience real, rather than borrowed fear, insult or rage" (2011, p. 150).

A present-day cruelty spills over into and fills the artistic space, being influenced by the scientific and technological progress. Violence does emerge as the means of bringing to life a genuineness of emotions, which has been long lost in the "thickets of technology". The one filming a video of this sort is "infected" with the victimized state and attains a pseudosatisfaction of his or her EN. This way the samsara wheel of technological violence is set in motion.

Žižek believes that there is a rather simple way of relief from violence, which differs from benign aggression caused by the urge to survive. The key to victory over violence, an excess of aggression, or "power of death" - is "the ability to die, to regain the innocence of nature, to find peace in getting rid of the obscene infinity of evil" (Žižek, 2008, p. 65). The difficulty is that while in a traditional society human life existed side by side with the death threats, in our time the technosphere envelopes a human being and isolates from the prospects of death as a cocoon. These circumstances result in pathological state of contemporary culture:

"We must recognize that our culture seems to be the only across all of human history which lacks a common understanding on the issue of Life and Death that is at least somewhat acceptable for society at large. The volumes have been written on the topic, but they all, including the meaningful fragments, are left on the side of the road" (Nalimov, 1994, p. 47). 
Guy Debord describes how technology advances give rise to a consumer society that unifies everyone and everything and turns even death into a product (2002, point 70), erosing its value. Automation leads to society itself turning into a performance that mixes up and equalizes all manifestations of human existence. Under these circumstances, violence becomes a commodity of the same sort and a part of the performance that finds its audience in people who are incapable of genuine creativity due to getting addicted to consumerism.

Here, we see a dual impact of the extensive cultural creativity. The first is the reduction of extensive creativity's (EC's) ethical potential, crisis of conscience, along with an axiological paradigm shift,

"putting a person into the new, previously inexistent circumstances that require the new comprehension and normativization [...] technoshpere changes the society too rapidly, not allowing the moral norms to establish firmly; their dynamics lags from the dynamics of society, because the understanding and acknowledgement of the norm that comprise morality needs time" (Stoletov, 2017).

Existence invisibly dwells behind the decline in understanding the connection between life and death as not only as a biological process, but as a certain state that is required for filling up with vital energy. Here, we find ourselves facing a glaring paradox. At one end, the post-industrial society provides favourable conditions for cultural activities and appropriate environment for innovation that is conducive to individual's natural artistic expression and creation. By contrast, when becoming a routine, an "obligation", creative activities may suppress self-realization. An excess of comfort and refinement move an individual further away from existence and induce to construct an artificial "limit situation". One way is to turn an attention to extreme sports and entertainment, placing an individual on the threshold between life and death. Others find this edge in the virtual reality of art, which gratifies the "death instinct" without a threat to the viewer's physical existence.

\section{Discussion}

Post-industrial society, which seemingly opens new significant opportunities for an individual's creative realization, regrettably does not eliminate the soil where looking at violence takes root. The underlying reason is the nature of the creative energy that led to the growth of contemporary technogenic culture. This is partially confirmed by recent research suggesting that creative activity per se does not give any indication of future moral development and does not contribute to the strength and soundness of a sense of good and evil (Gino \& Ariely, 2012, p. 455).

Creativity takes basically two forms: creativity as an occupation or a process of giving rise to something new differs from creativity derived from creator's personality or collective characteristics (Stoletov, 2016). Contemporary culture possesses a specific type of creative energy. Its emphasis on science and technology enhances EC, linked to the endeavor to explore the outside world, create and transform things and techniques.

Previous studies provide examples where body enveloped violations "were a form of entertainment providing much pleasure instead of disgust and horror in ancient Rome" (McNally, 2002, p. 564). As would be expected, aestheticization is the transformation of violence into entertainment. Nonetheless, ancient Roman dramaturgy and literature rendered violence 
entirely devoid of naturalism, if we compare them with contemporary examples cited in Section 1. In fact, Roman civilization was also geared towards a technological path as compared to its predecessor (Greece).

Another consequence lies in the fact that external expansionism and the extensive type of creativity is inextricably linked to violence. Inherently, expansion is violence that takes various shapes, from the consumerism (which requires increasingly more comfortable conditions, goods and services, and, by extension, technologies), up to aestheticism (which necessitates increasingly more refined ways to satisfy emotional hunger).

\section{Conclusions}

The danger in the escalation of aestheticizing depictions of violence in art lies in the specific social and unconscious reasons behind it.

Intensive creativity, focused on the inner source of inspiration and the existential nature, is shifted on the sociocultural periphery. Innovations shape and equip the outer world around human, but is unable itself to enrich the individual's inner world to the same extent.

Issues of violence and its manifestations in art emerged due to the shift in the type of creativity which constitutes cultural expressions. The EC focuses on exploring and transforming the outer world. This exploration is, in fact, a form of violence, realized in different ways in various activity and relationship spheres. Dealing with the ethical issues are secondary within this creative activity type. They are frequently of a highly utilitarian nature and accord with the way an individual considers the benefits. Thus one should not expect radical changes, including both the decrease in cruelty and its representation in art.

What is required is a change in the creative foundations of the society's culture, along with a balance between the extensive and intensive types of creativity. Future research may identify the criteria for the designation whether an artwork gives rise to, supports the violence level in a society or resists it.

\section{References}

Addison, N. (2011). The Dirtying of David: transgression, affect, and the potential space of art, Emotion, Space and Society, 4(3), 172-179. https://doi.org/10.1016/j.emospa.2010.09.004

Anderson Hudson, L., \& Wadkins, M. (1988). Japanese popular art as text advertising's clues to understanding the consumer. International Journal of Research in Marketing, 4(4), 267-272. https://doi.org/10.1016/0167-8116(88)90029-8

Artaud, A. (1994). The theater and its double. New York, NY: Grove Press.

Chetina, E. M. (2012). Ot "apofeoza bespochvennosti" - k "apofeozu nasiliya". Vestnik Permskogo Universiteta, 4(20), 144-148.

Corcoran, L., \& Lane, A. (2018). Exploring the Impact of off the Beaten Path: violence, women, and art. Women's Studies International Forum, 67, 72-79. https://doi.org/10.1016/j.wsif.2018.01.008

Debord, L. (2002). Society of the spectacle. Detroit: Black \& Red.

Fobear, K. (2017). “This painting is nice, but i wish it were more political". Exploring the challenges and dilemmas of community art with LGBT Refugees. Women's Studies International Forum, 62 (p. 52-60). https://doi.org/10.1016/j.wsif.2017.02.002 
Fromm, E. (2013). Escape from freedom. New York: Henry Holt and Company, L.L.C.

Fromm, E. (1973). The anatomy of human destructiveness. New York: Henry Holt and Company "An Owl Book".

Gino, F., \& Ariely, D. (2012). The dark side of creativity: original thinkers can be more dishonest. Journal of Personality and Social Psychology, 102(3), 445-459. https://doi.org/10.1037/a0026406

Lee, B. X. (2016). Causes and cures IV: the symbolism of violence. Aggression and Violent Behavior, 27, 152-157. https://doi.org/10.1016/j.avb.2016.03.002

Lessing, G. E. (1953). Izbrannyye proizvedeniya. Moskva: Gosudarstvennoe izdatel'stvo hudozhestvennoj literatury.

Lobastov, Y. (2009). Problema nasiliya v iskusstve i deystvitel'nosti. Svobodnaya Mysl, 12(1607), 101-112.

Maffesoli, M. (1989). La socialidad en la postmodemidad. Pergola, 8, 100-124.

Martin, G. R. R. (1996). A song of ice and fire. Bk.: A Game of Thrones. New York: Bantam Books.

Martin, G. R. R. (1998). A song of ice and fire. Bk.: A Clash of Kings. New York: Bantam Books.

Martin, G. R. R. (2000). A song of ice and fire. Bk.: A Storm of Swords. New York: Bantam Books.

Martin, G. R. R. (2005). A song of ice and fire. Bk.: A Feast for Crows. New York: Bantam Books.

Martin, G. R. R. (2011). A song of ice and fire. Bk.: A Dance with Dragons. New York: Bantam Books.

Martin, G. R. R. (Forthcoming a). A song of ice and fire. Bk.: The Winds of Winter. New York: Bantam Books.

Martin, G. R. R. (Forthcoming b). A song of ice and fire. Bk.: A Dream of Spring. New York: Bantam Books.

McNally, R. J. (2002). Disgust has arrived. Journal of Anxiety Disorders, 16(5), 561-566. https://doi.org/10.1016/S0887-6185(02)00174-3

Mumford, L. (2004). Mif o mashine: tehnika i razvitie cheloveka. Moskva: Logos.

Naisbitt, J. (2001). High tech, high touch: technology and our accelerated search for meaning. London: Nicolas Brealey Publishing.

Nalimov, V. V. (1994). Na grani tret'yego tysyacheletiya: chto osmyslili my, priblizhayas' $k$ XXI veku. Moskva: Labirint.

Nekrasova, E. S. (2011). "Novaya zhestokost” kak primer dlya podrazhaniya. Mezhdunarodnyy Zhurnal Issledovaniy Kul'tury, 2(3), 146-150.

Nemchenko, L. M. (2013). Nasiliye kak povsednevnaya praktika mirnoy zhizni i sovremennogo iskusstva. In L. A. Zaks et al. (Eds.), Rossiya v mire XXI veka: mezhdu nasiliyem i dialogom, Materialy XVI Mezhdunarodnoj nauchno-prakticheskoj konferencii Gumanitarnogo universiteta. Vol. 1. Ekaterinburg: Avtonomnaja nekommercheskaja organizacija vysshego obrazovanija "Gumanitarnyj universitet" (pp. 136-140).

Nemchenko, L. M., \& Temlyakova, A. S. (2015). Reprezentatsiya nasiliya (na materiale kinematografa Ul'rikha Zaydlya), Izvestija Ural'skogo federal'nogo universiteta. Serija 3. Obshhestvennye nauki, 10(1). Retrieved from https://journals.urfu.ru/index.php/Izvestia3/article/view/1206

Ortega y Gasset, J. (1932). The revolt of the masses. New York: W. W. Norton and Company, Inc.

Rodionov, S. N. (2008). Kul'tura postmoderna i iskusstvo Zapada: "Nasiliye smysla" v prostranstve simulyatsii i imitatsii. Kul'turnaya Zhizn’ Yuga Rossii, 2(28), 30-32.

Shestov, L. (1920). All things are possible. New York: Robert M. McBride \& Co.

Stoletov, A. I. (2017). Problema nravstvennosti v sovremennom tekhnogennom obshchestve. Nota Bene. Retrieved from http://nbpublish.com/library_read_article.php?id=23788

Stoletov, A. I. (2016). Social creativity and phenomenon of success in postindustrial society. Creativity Studies, 9(2), 141-150. https://doi.org/10.3846/23450479.2016.1223765 
Tropina, I. G. (2009). Katarsicheskaya funktsiya ekrannogo nasiliya. Izvestiya Volgogradskogo Gosudarstvennogo Pedagogicheskogo Universiteta, 8, 12-18.

Tzavaras, N., Krasanakis, S., \& Giannoulaki, C. (2013). 2272 - art and psychiatry a discourse between psychoanalytic thought and cinema. European Psychiatry, 28(1), 1. https://doi.org/10.1016/S0924-9338(13)77133-5

United Nations, General Assembly. (2015). Transforming our world: The 2030 agenda for sustainable development. Resolution adopted by the General Assembly on 25 September 2015. Retrieved from https://www.unfpa.org/sites/default/files/resource-pdf/Resolution_A_RES_70_1_EN.pdf

Vladimirovich Ferroni, V. (2015). "Esteticheskiy" modus sushchestvovaniya cheloveka kak prichina prestupnogo nasiliya. Vestnik Voronezhskogo Instituta FSIN Rossii, 1, 104-109.

Wilde, O. (2000). The picture of Dorian Gray. Harmondsworth: Penguin Classics.

Winnicott, D. W. (1971). Playing and reality. London and New York: Routledge.

Žižek, S. (2008). Violence: six sideways reflections. Series: Big Ideas/Small Books. New York: Picador.

\section{KAIP IŠPLĖSTINIS KŪRYBIŠKUMAS SUSIJĘS SU SMURTO ESKALAVIMU MENE?}

\section{Anatoliy IGOREVICH STOLETOV, Rushana KHUSAINOVNA LUKMANOVA, Miliausha FARITOVNA SIRAZETDINOVA, Ksenia VYACHESLAVOVNA KHRAMOVA, Olesya GENNADYEVNA AFANASYEVA}

\section{Santrauka}

Filmuose, dramaturgijoje ir literatūroje vis daugiau demonstruojama žiaurumo epizodų personažų santykiuose. Susitelkiant ị esmines idejjas augančio smurto klausi$\mathrm{mu}$, šiame straipsnyje nagrinejjamos pagrindinès priežastys, dèl kurių smurtas mene tapo ypač dažnai vaizduojamas. Straipsnyje atskleidžiami socialiniai, kultūriniai ir antropologiniai veiksniai, prisidejję prie formavimosi technosferos, trukdančios suprasti gyvenimo bei mirties santykị ir priešpriešą. Be šio supratimo kultūrinè disfunkcija sukelia egzistencinę krizę, neleidžia išgyventi pilnutinès gyvasties jausmo ir provokuoja „saugų“ virtualų būdą sukelti apribojimo situaciją, kuri atkuria "gyvenimo integralumo" patirtị. Menas, demonstruojantis smurto scenas, yra vienas iš šių metodų. Be to, tai pirmasis straipsnis, kuriame analizuojamas šis plataus kūrybiškumo tipas, vyraujantis postindustrinès visuomenès kultūroje. Tyrimas rodo, kad platus kūrybiškumas neapima etinio komponento ir nestiprina imuniteto smurtui. Priešingai, nukreipiant individą i i išorinio pasaulio tyrinejjimą ir keitimą, provokuojamas smurtas, nes ekspansijos pobūdis a priori yra priverstinis. Autoriai daro išvadą, kad smurto eskalavimas mene liudija apie kultūrinių metodų, leidžiančių patenkinti egzistencinius asmens poreikius, trūkumą.

Reikšminiai žodžiai: agresija, šiuolaikinis menas, žiaurumas, egzistenciniai poreikiai, platus kūrybiškumas, filmas, technogeninè civilizacija, smurtas. 